Плодоводство и виноградарство Юга России № 52(04), 2018 г.

УДК 663.2

DOI: 10.30679/2219-5335-2018-4-52-96-109

ИСПОЛЬЗОВАНИЕ НОВЫХ СОРТОВ ВИНОГРАДА ДЛЯ ВЫСОКОКАЧЕСТВЕННЫХ ВИН ЮГА РОССИИ

Гугучкина Татьяна Ивановна

д-р с.-х. наук, профессор

заведующая НЦ «Виноделие»

Антоненко Михаил Викторович

канд. техн. наук

ст. научный сотрудник

НЦ «Виноделие»

Федеральное государственное бюджетное научное учреждение «Северо-Кавказский федеральный научный центр садоводства, виноградарства, виноделия», Краснодар, Россия

Проведен обзор нормативной и законодательной документации, на основании которой вводится организация производства вин защищенных географических указаний (ЗГУ) и защищенных наименований места происхождения (ЗНМП) в России и Краснодарском крае. Предложена классификация российских вин, включающая вина высшей категории. Рассмотрены основные требования к винам ЗГУ и ЗНМП в соответствии с действующим стандартом ГОСТ Р 55242-2012 «Вина защищенных географических указаний и вина защищенных наименований места происхождения. Общие технические условия». Предложены сорта винограда местной селекции, обладающие высокой продуктивностью, устойчивостью к грибным болезням, филлоксере и морозам (выдерживают минус $25-28^{\circ} \mathrm{C}$ ), стабильностью плодоношения и высокими органолептическими свойствами. Все сорта винограда были созданы российскими селекционерами ведущих научных
UDC 663.2

DOI: 10.30679/2219-5335-2018-4-52-96-109

\section{USING OF NEW \\ GRAPE VARIETIES \\ FOR HIGH QUALITY WINES OF THE SOUTH OF RUSSIA}

\author{
Guguchkina Tatyana Ivanovna \\ Dr. Sci. Agr., Professor \\ Head of SC «Wine-making»
}

Antonenko Mikhail Victorovich

Cand. Tech. Sci.

Senior Research Associate

of CS "Wine-making

Federal State Budget

Scientific Institution

"North Caucasian Federal

Scientific Center of Horticulture,

Viticulture, Wine-making»,

Krasnodar, Russia

The review of normative and legislative documentation for the organization of the wine production of protected geographical indication (PGI) and protected appellation of origin (PAO) in Russia and in the Krasnodar Region is carried out. The classification of Russion wines, including of hight category is offered. The main requirements for PGI and PAO wines are considered in accordance with the current standard GOST R 55242-2012

"Wines with protected geographical indication and wines with protected appellation of origin. General specifications". Grapes varieties of local breeding possessed are highly productive, resistant to fungal diseases, phylloxera and frost (withstand minus $25-28^{\circ} \mathrm{C}$ ), fruiting stability and high organoleptic properties are offered. All varieties of grapes were created by Russian breeders in the leading scientific institutions of Russia. The objects of research 
учреждений России. Объектами исследований являлись белые и красные виноматериалы, выработанные в условиях микровиноделия ФГБНУ СКФНЦСВВ, и столовые вина, выработанные предприятиями Краснодарского края из технических сорта винограда. Исследования выполнялись в научном центре «Виноделие» СКФНЦСВВ с использованием общепринятых и действующих на территории РФ стандартов, а также оригинальных методик на базе капиллярного электрофореза, газожидкостной хроматографии, хромато-масс-спектрометрии и электрохимического титрования. Высокое качество вин из местных сортов подтверждено в ходе дегустации «Антицея-2016» в Северо-Кавказском зональном научно исследовательском институте садоводства и виноградарства (ныне ФГБНУ СКФНЦСВВ). Приведены агротехнические характеристики выделившихся белых и красных сортов винограда. Особое внимание уделено винам, полученным из винограда Достойный Красностоп анапский, которые имеют высокие органолептические характеристики и могут расширить ассортимент высококачественных вин ЗГУ и ЗНМП на юге России.

Ключевые слова: ВИНО, КЛАССИФИКАЦИЯ РОССИЙСКИХ ВИН, СОРТ ВИНОГРАДА, КАЧЕСТВО ВИНОПРОДУКЦИИ were white and red wine materials, developed in the conditions of micro wine-making of FSBSF of NCFSCHVW, and table wines produced by enterprises of the Krasnodar Territory from technical grape varieties. The research was carried out in the Scientific Center "Winery" NCFSCHVW using the well-known and operating in the Russian Federation standards, as well as original techniques based on capillary electrophoresis, gas-liquid chromatography, chromato-mass spectrometry and electrochemical titration. The high quality of wines from local varieties was confirmed during the tasting of "Antitseya-2016" in the North Caucasian Regional Research Institute of Horticulture and Viticulture (now FSBSI NCFSCHVW). The agrotechnical characteristics Of white and red selected grape Varieties are given. Particular attention was paid to the wines obtained from the grape varieties Dostoyny and Krasnostop Anapsky with high organoleptic characteristics, which can expand the assortment of high-quality wines in the South of Russia, including PGI and PAO.

Key words: WINE, CLASSIFICATION

OF RUSSIAN WINES, GRAPE

VARIETY, QUALITY

OF WINE PRODUCTION

Введение. Современная виноградовинодельческая отрасль агропромышленного комплекса России является экономически и социально значимой. Производство винограда более доходно по сравнению с производством однолетних культур, в частности, доход с одного гектара плодоносящих насаждений винограда в 8,7 раза больше дохода от производства зерна озимой пшеницы. По данным Е.А. Егорова, промышленное виноградарство вовлекает в процесс производства значительные трудовые ресур- 
сы: 100 га виноградных насаждений создают до 40 постоянных рабочих мест, а с учетом винодельческого производства - 60 рабочих мест [1]. Это способствует повышению занятости населения и росту его благосостояния.

Постановлением Правительства РФ №1912 от 19.12. 2014 г. в Государственную программу развития виноградарства на период до 2020 года внесены следующие целевые индикаторы: доведение площадей виноградных насаждений до 140 тыс. га, объемов производства винограда до 700 тыс. тонн, ежегодных площадей закладки виноградников до 9,1 тыс. га в год (против 3,2 тыс. га в 2014 г.). Обеспеченность винодельческой промышленности собственным сырьем должна составить $55 \%$ (сейчас $25 \%$ ). Для того, чтобы достичь таких результатов, необходимо экстренно развивать российскую питомниководческую базу и быстрыми темпами увеличивать посадки винограда.

В настоящее время исследования по виноградарству и виноделию в Краснодарском крае стали выполняться на более современном уровне с учетом ампелографического описания сортов и клонов с дополнительным ДНК маркированием [2-5], что позволяет проводить апробацию сортов винограда на идентичность и изучать их биологическое разнообразие [6-11].

В связи с этим нами, в содружестве с Л.П. Трошиным (КубГАУ) и сотрудниками научного центра виноградарства института проводятся исследования по совершенствованию технических сортов винограда на основе клоновой селекции [12]. Установлено, что выделенные клоны винограда отличаются от контрольных сортов не только агробиологической, но и генетической характеристикой и являются, как показывают исследования, самостоятельными сортами. В настоящее время выделенные клоны переданны в Государственное сортоиспытание. Среди них: Алиготе фанагорийское, Каберне фанагорийское, Мерло фанагорийское, Саперави фанагориский, Совиньон фанагорийский, Рислинг фанагорийский, Алиготе Залив, Гранатовый (клон), Рислинг Черноморец и др. 
Исследования в области виноделия с целью получения эксклюзивных качественных вин могут быть проведены также с использованием интродуцированных сортов, что значительно ускорит и расширит их ассортимент винопродукции [13-15]. Среди интродуцированных сортов выделяются клоны Сира 174, Сира 470, Сира 585, Санджовезе VCR 23, 169, Анчеллотта R338, Мерло R3, 685. Из них сортов можно готовить как столовые, так и ликерные красные вина. Следует отметить значимость сорта винограда Инкрочо Манзони для производства высококачественных белых вин [6].

На Кубани нет сортов винограда с более чем вековой историей или автохтонных сортов, так как история развития большинства промышленных винодельческих предприятий отрасли сама насчитывает чуть более полувека. Так, бывший Старотитаровский винзавод (нынешний ОАО «Кубань-Вино») существует с 1956 года. Поэтому завезенные из Югославии, Франции, Германии, Австрии и других стран классические сорта и клоны винограда стали для России традиционными.

Объекты и методы исследований. Исследования выполнялись на базе научного центра «Виноделие» ФГБНУ СКФНЦСВВ с использованием общепринятых и действующих на территории РФ стандартов, а также оригинальных методик на базе капиллярного электрофореза, газожидкостной хроматографии, хромато-масс-спектрометрии и электрохимического титрования с использованием оборудования ЦКП «Приборно-аналитический» СКФНЦСВВ. Объектами исследований являлись белые и красные виноматериалы, выработанные в условиях микровиноделия ФГБНУ СКФНЦСВВ, и столовые вина, выработанные предприятиями Краснодарского края из технических сорта винограда.

Обсуждение результатов. Селекционный фонд отечественных сортов винограда и виноградарство будущего должно базироваться на высокоадаптивных, высококачественных, стабильно продуктивных и высоко- 
Плодоводство и виноградарство Юга России № 52(04), 2018 г.

технологичных сортах винограда, дающих эксклюзивную винодельческую продукцию. Дегустация вин «Антицея-2016», проведенная в институте, показала, что такие сорта есть. Они созданы российскими селекционерами, работавшими и продолжающими работать в СКФНЦСВВ в разные годы (Коханова Л.Т., Нудьга Т.А.), во ВНИИВиВ им. Я.И. Потапенко (Красохина С.А., Кострикин И.Л., Сьян И.Н., Майстренко Л.А, Майстренко А.Н. и др.), АЗОСВиВ (Зоткина Г.А., Никулушкина Г.Е., Апалькова Н.Н., Панкин М.И., Дергунов А.В.), НИВиВ «Магарач» (Голодрига П.Я., Трошин Л.П., Костик М.А.) и другими учеными-селекционерами.

В дегустации участвовало 78 вин, приготовленных как из белых, так и красных сортов винограда. Агротехнические характеристики выделившихся сортов винограда представлены в табл. 1, 2.

Таблица 1 - Агротехническая характеристика белых сортов винограда, вина которых участвовали в конкурсе «Антицея-2016»

\begin{tabular}{|c|c|c|c|c|}
\hline Сорт & Родительские пары & $\begin{array}{c}\text { Урожайность, } \\
\text { т/га }\end{array}$ & $\begin{array}{c}\text { Срок } \\
\text { созревания } \\
\text { винограда }\end{array}$ & $\begin{array}{c}\text { Морозо- } \\
\text { устойчивость }\end{array}$ \\
\hline Бархатный & $\begin{array}{c}\text { Кировобадский столовый х } \\
\text { Мускат гамбургский }\end{array}$ & 16 & Среднепоздний & $\begin{array}{l}\text { Низкая, } \\
-18^{\circ} \mathrm{C}\end{array}$ \\
\hline Виорика & Алеатико х Зейбель 13666 & $9,0-10,0$ & $\begin{array}{l}\text { Среднепоздний } \\
(145-150 \text { дней) }\end{array}$ & $\begin{array}{c}\text { Хорошая, } \\
-22^{\circ} \mathrm{C}\end{array}$ \\
\hline Платовский & $\begin{array}{c}\text { Зала дендье x } \\
\text { Подарок Магарача }\end{array}$ & 30 & $\begin{array}{c}\text { Очень раннего } \\
\text { срока } \\
\text { созревания } \\
\text { (110-115 дней) }\end{array}$ & $\begin{array}{l}\text { Высокая, } \\
-29^{\circ} \mathrm{C}\end{array}$ \\
\hline $\begin{array}{c}\text { Мускат } \\
\text { аксайский }\end{array}$ & $\begin{array}{c}\text { Степняк х } \\
\text { Мискет кайлышски }\end{array}$ & $10,0-11,0$ & $\begin{array}{c}\text { Очень позднего } \\
\text { срока } \\
\text { созревания } \\
\end{array}$ & $\begin{array}{l}\text { Высокая, } \\
-25^{\circ} \mathrm{C}\end{array}$ \\
\hline Цветочный & $\begin{array}{c}\text { Северный х смесь пыльцы } \\
\text { мускатных сортов }\end{array}$ & $8,0-13,6$ & $\begin{array}{c}\text { Среднепозднего } \\
\text { срока } \\
\text { созревания } 145 \\
\text { дней }\end{array}$ & $\begin{array}{c}\text { Повышенная, } \\
-25^{\circ} \mathrm{C}\end{array}$ \\
\hline
\end{tabular}

Из табл. 1 видно, что все выделившиеся белые сорта винограда имели мускатный аромат. Среди них Цветочный, Бархатный, Платовский, Мускат аксайский, Цитронный Магарача. Среди красных по органолептическим 
свойствам выделились все три Красностопа: Красностоп золотовский, Красностоп АЗОС, Красностоп анапский (табл. 2). Самым морозоустойчивым среди белых сортов является сорт виногнрада Платовский, выдерживающий температуру минус $29{ }^{\circ} \mathrm{C}$; среди красных - Левокумский - минус $32{ }^{\circ} \mathrm{C}$. На рис. 1 представлен сорт винограда Достойный, производство продукции из которого уже осуществляется в промышленном масштабе.

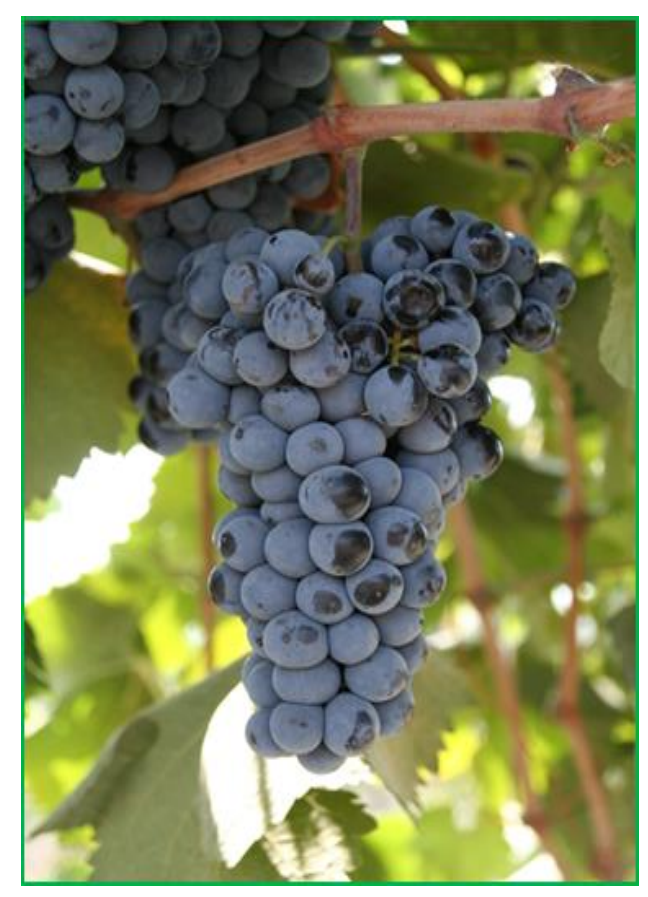

Рис. 1. Сорт винограда Достойный

Достойный - сорт винограда позднего срока созревания, созданный селекционерами АЗОСВиВ. Родителями этого красного сорта винограда являются Филлоксероустойчивый Джемете и Мускат гамбургский. Выращивается сорт в «Винодельне Юбилейная» Темрюкского района Краснодарского края. Площади под виноградниками составляют 52 га, а в ближайшие годы добавятся еще 100 га виноградников этого сорта, который имеет высокую урожайность (11,5-13,0 т/га), хорошо накапливает сахар (до 25 г/100 см ${ }^{3}$ ) при умеренной кислотности. С.В. Дубровин (директор хозяйства) так характеризует этот сорт: «Сильнорослый, морозостойкий, выдерживает минус $22^{\circ} \mathrm{C}$, не болеет, с кустом работать интересно. 
Плодоводство и виноградарство Юга России № 52(04), 2018 г.

В зависимости от величины нагрузки дает разную по интенсивности окраску вин. В процессе хранения вина фенольные вещества не выпадают, что очень важно при выдержке вина, особенно в бутылке».

Таблица 2 - Агротехническая характеристика красных сортов винограда, вина которых участвовали в конкурсе «Антицея-2016»

\begin{tabular}{|c|c|c|c|c|}
\hline Сорт & Родительские пары & $\begin{array}{c}\text { Урожайность, } \\
\text { т/га }\end{array}$ & $\begin{array}{c}\text { Срок созревания } \\
\text { винограда }\end{array}$ & $\begin{array}{c}\text { Морозо- } \\
\text { устойчивость }\end{array}$ \\
\hline Достойный & $\begin{array}{l}\text { Филлоксероустойчивый } \\
\text { Джемете х } \\
\text { Мускат гамбургский }\end{array}$ & $11,0-13,0$ & Поздний & $\begin{array}{c}\text { На уровне } \\
\text { Муската } \\
\text { Гамбурского, } \\
-22^{\circ} \mathrm{C}\end{array}$ \\
\hline $\begin{array}{l}\text { Красностоп } \\
\text { АЗОС }\end{array}$ & $\begin{array}{l}\text { Филлоксероустойчивый } \\
\text { Джемете х } \\
\text { Красностоп анапский } \\
\end{array}$ & 12,0 & Средний & $\begin{array}{c}\text { Высокая, } \\
-24^{\circ} \mathrm{C}\end{array}$ \\
\hline $\begin{array}{l}\text { Красностоп } \\
\text { золотовский }\end{array}$ & $\begin{array}{l}\text { Старинный донской } \\
\text { сорт }\end{array}$ & $6,0-7,0$ & Среднепоздний & $\begin{array}{c}\text { Высокая, } \\
-26^{\circ} \mathrm{C}\end{array}$ \\
\hline Гранатовый & $\begin{array}{l}\text { Саперави х } \\
\text { Каберне Совиньон }\end{array}$ & $12,0-14,0$ & $\begin{array}{c}\text { Поздний, } \\
\text { III декада сентября }\end{array}$ & $\begin{array}{c}\text { Средняя, } \\
-22^{\circ} \mathrm{C} \\
\end{array}$ \\
\hline Алькор & $\begin{array}{l}\text { Серексия х } \\
\text { Каберне Совиньон }\end{array}$ & 15,0 & Среднепоздний & $\begin{array}{c}\text { Средняя, } \\
-22^{\circ} \mathrm{C}\end{array}$ \\
\hline $\begin{array}{l}\text { Одесский } \\
\text { черный }\end{array}$ & $\begin{array}{l}\text { Аликант Буше х } \\
\text { Каберне Совиньон }\end{array}$ & $12,0-13,0$ & $\begin{array}{c}\text { Поздний, } \\
\text { IV декада } \\
\text { сентября }\end{array}$ & $\begin{array}{c}\text { Повышенная, } \\
-24^{\circ} \mathrm{C}\end{array}$ \\
\hline Левокумский & $\begin{array}{l}\text { Сорт народной } \\
\text { селекции }\end{array}$ & $17,0-18,0$ & Средний & $\begin{array}{c}\text { Высокая, } \\
-32^{\circ} \mathrm{C}\end{array}$ \\
\hline $\begin{array}{l}\text { Саперави } \\
\text { северный }\end{array}$ & Северный х Саперави & $7,2-11,5$ & $\begin{array}{l}\text { Поздний, } \\
\text { 140-145 дн. }\end{array}$ & $\begin{array}{c}\text { Высокая, } \\
-26^{\circ} \mathrm{C}\end{array}$ \\
\hline $\begin{array}{l}\text { Красностоп } \\
\text { анапский }\end{array}$ & $\begin{array}{l}\text { Клон Красностопа } \\
\text { золотовского }\end{array}$ & $9,0-11,0$ & Среднепоздний & $\begin{array}{c}\text { Высокая, } \\
-28^{\circ} \mathrm{C}\end{array}$ \\
\hline
\end{tabular}

Учеными показано, что сорт Достойный можно использовать как в производстве высококачественных столовых сухих, ликерных вин, так и соков. При этом дегустационная оценка ликерного вина составляет 8,8 балла, сухого - 8,4-8,6. Вина из этого сорта винограда имеют темно-рубиновую окраску, полный гармоничный вкус, терново-ежевичные тона в аромате с хорошо сочетающимися легкими цветочно-мускатными оттенками. Вино из винограда сорта Достойный содержит большое количество биологически ценных веществ, как и все красные сорта селекции АЗОСВиВ. 
Плодоводство и виноградарство Юга России № 52(04), 2018 г.

Ярким событием для вина из сорта Достойный стало получение награды в виде Кубка Союза виноградарей и виноделов России (СВВР-2017) и звание «Лучшее красное вино России 2017 года».

Красностоп анапский - клон винограда Красностоп золотовский, выделенный селекционерами АЗОСВиВ в 1953 году как более крупноягодный и урожайный сорт. Виноградники АФ «Южная» Темрюкского района имеют этот сорт в насаждениях на площади 124,86 га, которая в ближайшее время увеличится еще на 300 га. На предприятии ООО «КУБАНЬ-ВИНО» из этого сорта выпускаются столовые, ликерные, географического наименования различные линейки вин, выдержанные и без выдержки: Шато Тамань, Шато Тамань резерв, Шато Тамань селект и другие, которые имеют награды международных и региональных конкурсов: «Мувине» (Словения), «Шато Тамань. Красностоп Тамани» - золотая медаль; «Антицея-2016» (Россия), «Красностоп. Шато Тамань резерв» - золотая медаль; «Кубок СВВР - 2016» (Россия), «Красностоп. Шато Тамань резерв», урожай 2014 - золотая медаль.

В Краснодарском крае распространено более 80 наименований сортов винограда. В основном это сорта, завезенные из Европы, такие как Алиготе, Шардоне, Рислинг, Каберне Совиньон, Мерло и их высокопродуктивные клоны, а также внутривидовые гибриды вида Vitis vinifera: Гранатовый, Алькор, Мицар, Антарис и др. Кроме сортов, представленных выше, хорошо зарекомендовали себя следующие белые и красные сорта: Бархатный, Красностоп золотовский (анапский), Одесский черный и гибриды межвидового происхождения Цитронный Магарача, Виорика, Платовский, Мускат аксайский, Цветочный.

Позднее были созданы межвидовые гибриды с более высокой морозостойкостью и устойчивостью к болезням и вредителям - Дмитрий, Владимир, Курчанский, Екатеринодарский, которые выдерживают зимой и в период возвратных февральских холодов температуру минус $22-26{ }^{\circ} \mathrm{C}$. 
Плодоводство и виноградарство Юга России № 52(04), 2018 г.

Расширение ассортимента высококачественных вин из винограда различных сортов в Краснодарском крае также может происходить за счет сортов биологического земледелия: Солярис, Йоханитр, Бачка, Морава, Кернер (рис. 2-5).

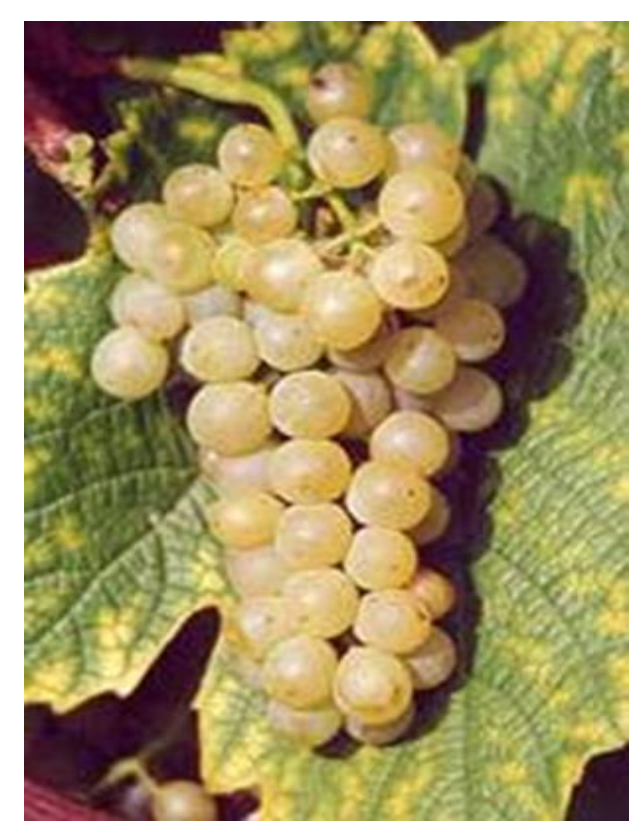

Рис. 2. Сорт винограда Солярис

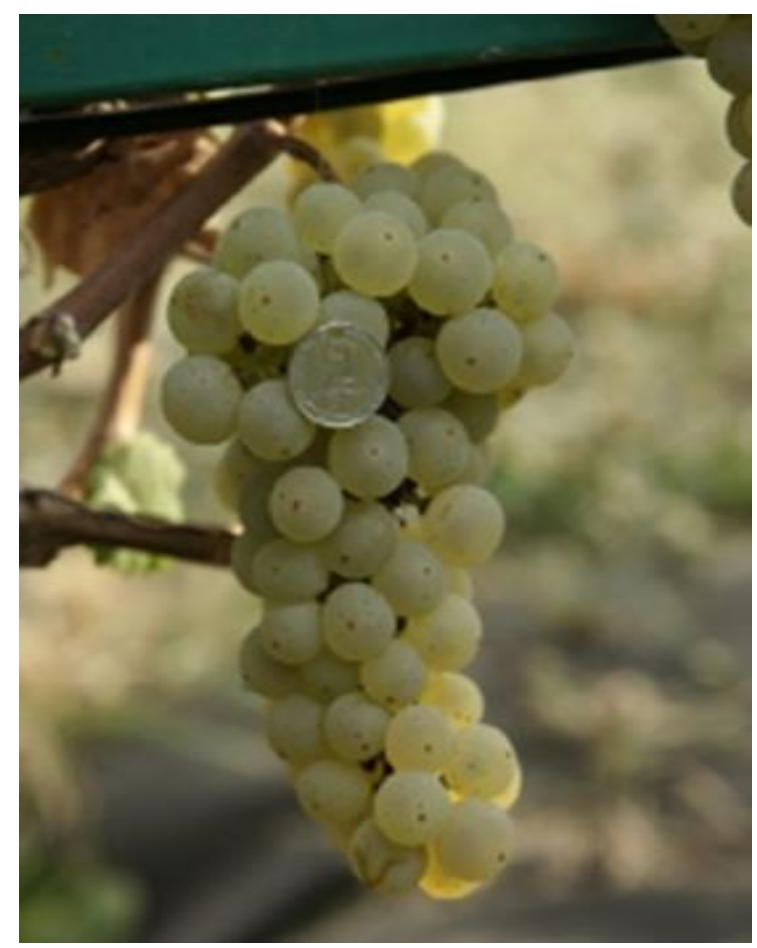

Рис. 3. Сорт винограда Йоханитр

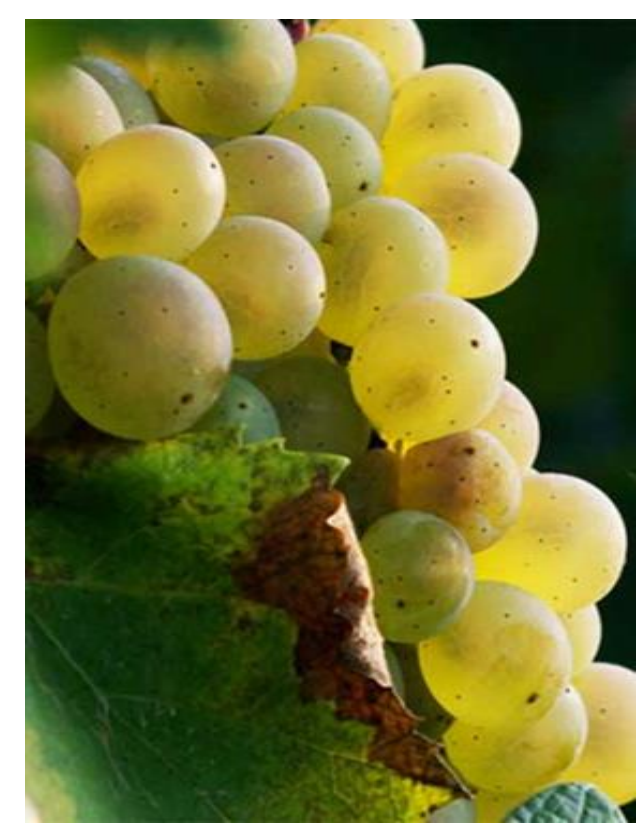

Рис. 4. Сорт винограда Бачка

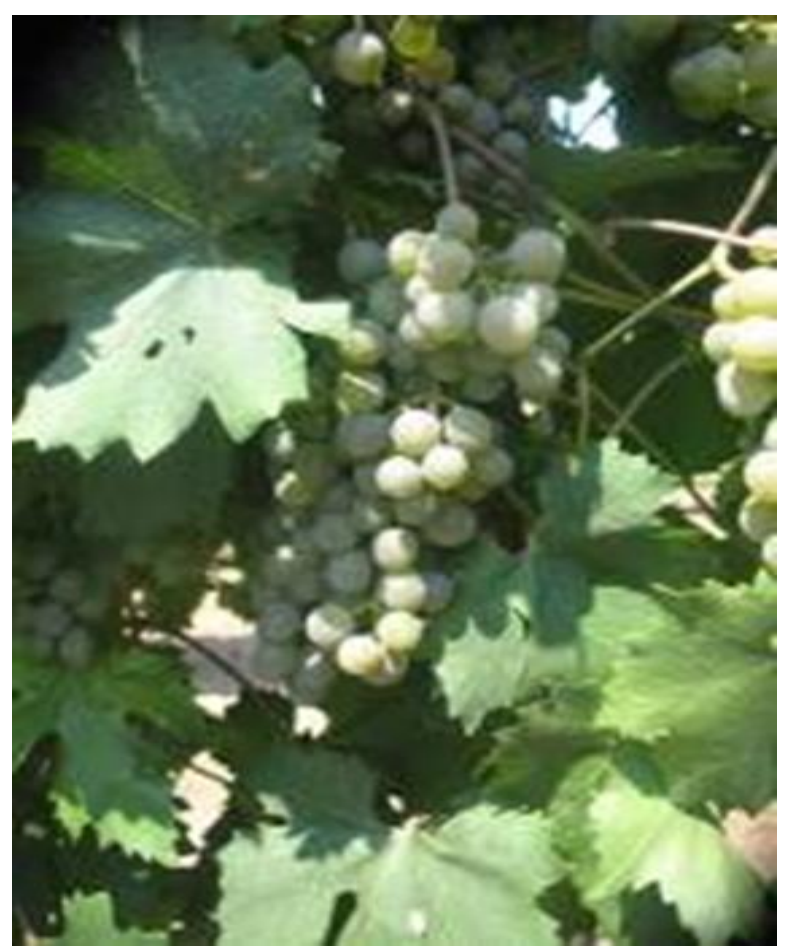

Рис. 5. Сорт винограда Морава 
Плодоводство и виноградарство Юга России № 52(04), 2018 г.

Из интродуцированных сортов и клонов винограда высокое качество вин и столовых, и ликерных из года в год демонстрируют Анчеллотта, Сира, Санджовезе, Инкрочо Манзони. Технологическая направленность использования всех этих сортов винограда в настоящее время - производство столовых, вин географических наименований, ликерных, игристых вин, включая вина ЗГУ и ЗНП.

Селекционный фонд отечественных сортов винограда всё время пополняется как за счет внутривидовых гибридов Тана 33 (Vitis Vinifera), так и европейско-американских и европейско-амурских гибридов: Тана 62, Тана 68, Тана 24/1,Тана 24, Тана 42 (Курчанский), Тана 85, Тана 87, Прогресс, Горный, Дионис, Магия, Августа, Шатен, Фиалковый.

Сотрудниками НЦ «Виноделие» рекомендуются к внедрению высокоэффективные технологии, позволяющие применять существующие новации в сортовой политике [6-9]:

- технология малоокисленных вин из винограда сортов селекции СКФНЦСВВ и АЗОСВиВ;

- технология белых столовых вин на основе интенсификации спиртового брожения;

- технология красных вин с применением сульфомацерации;

- технология игристых вин с использованием криоконцентрата;

- технология соков функционального назначения и другие.

Многолетние исследования научного центра «Виноделие» СКФНЦСВВ [10-12], проведенные с применением современного высокоточного аналитического оборудования, наглядно свидетельствуют о том, что местные красные сорта винограда обладают достаточно высоким технологическим запасом фенольных соединений, характеризуются высокими значениями антиоксидантной активности (AOA), и дают стабильно высокие органолептические оценки, не уступая по этим показателям известным 
Плодоводство и виноградарство Юга России № 52(04), 2018 г.

европейским сортам (табл. 3), о чем свидетельствуют многочисленные золотые награды и Гран-при международных конкурсов: «Ялта. Золотой Грифон 2005, 2009, 2010-2016»; «Золотая осень» 2010, 2016, (Москва).

Таблица 3 - Технологический запас фенольных соединений красных сортов винограда и дегустационная оценка столовых сухих красных вин

\begin{tabular}{|c|c|c|c|c|}
\hline Copт & $\begin{array}{c}\text { Технологический } \\
\text { запас фенольных } \\
\text { соединений (ФС) } \\
\text { в винограде, } \\
\text { мг/дм }\end{array}$ & $\begin{array}{l}\text { Сумма ФС } \\
\text { в винах, } \\
\text { мг/дм }{ }^{3}\end{array}$ & $\begin{array}{c}\text { AOA в винах } \\
\text { в пересчете } \\
\text { на TROLOX, } \\
\text { мг/дм }{ }^{3}\end{array}$ & $\begin{array}{l}\text { Дегустационная } \\
\text { оценка (средняя } \\
\text { за 2009-2017 г.г) }\end{array}$ \\
\hline \multicolumn{5}{|c|}{ Сорта селекиии СКФНЦСВВ } \\
\hline Алькор & 6680 & 3860 & 670 & 9,4 \\
\hline Гранатовый & 5870 & 3100 & 715 & 9,5 \\
\hline Антарис & 6310 & 3630 & 824 & 9,5 \\
\hline Мицар & 5680 & 2890 & 587 & 9,7 \\
\hline Сацимлер & 6350 & 3400 & 650 & 9,3 \\
\hline Владимир & 6200 & 3529 & 818 & 8,5 \\
\hline Дмитрий & 6450 & 3603 & 840 & 8,4 \\
\hline \multicolumn{5}{|c|}{ Сорта селекции АЗОСВиВ } \\
\hline Каберне АЗОС & 5830 & 3870 & 836 & 8,8 \\
\hline Достойный & 5230 & 3200 & 564 & 9,2 \\
\hline $\begin{array}{l}\text { Красностоп } \\
\text { анапский }\end{array}$ & 6950 & 4330 & 910 & 9,6 \\
\hline Красностоп АЗОС & 6310 & 4250 & 885 & 9,6 \\
\hline Гармония & 6180 & 3870 & 754 & 8,9 \\
\hline Кубанец & 6050 & 3800 & 750 & 8,7 \\
\hline \multicolumn{5}{|l|}{ Контроль } \\
\hline Мерло & 5100 & 2410 & 424 & 8,2 \\
\hline Каберне Совиньон & 5680 & 3650 & 568 & 9,4 \\
\hline
\end{tabular}

Вина, приготовленные из винограда технических сортов Гранатовый, Антарис, Мицар еще раз подтвердили свое высокое качество, получив только в 2016 году 8 золотых и 1 серебряную медали. Фермеры, тесно со- 
Плодоводство и виноградарство Юга России № 52(04), 2018 г.

трудничающие с учеными, также начинают получать достойные награды за вина из этих сортов винограда - Фермерская удача, Фермерская надежда, Фермерская мечта.

Рекомендуемые учеными направления использования сортов винограда - производство столовых вин, биовин, игристых вин, в том числе защищенных географических указаний, защищенных наименований места происхождения, выдержанных и без выдержки, соков и коньяков.

Заключение. Таким образом, селекционерами СКФНЦСВВ, АЗОСВиВ, ВНИИВиВ им. Я.И. Потапенко, ИВиВ «Магарач» в результате многолетних исследований были созданы высокоадаптивные технические сорта винограда, обладающие высокой продуктивностью, стабильностью плодоношения, устойчивостью к грибным болезням, филлоксере и морозам, и, главное, высоким качеством продукции.

Из винограда технических сортов юга Российской Федерации можно производить эксклюзивные вина, что подтверждается производственным опытом и большим количеством наград.

Активная сортовая и агротехническая политика виноградарей, технологически выверенные мероприятия специалистов винодельческой отрасли позволяют винам России быть оригинальными, не похожими на другие, иметь заслуженный успех у потребителя, удовлетворять потребностям современного рынка, а в будущем обеспечить независимость от импортных поставок вина.

\section{Литература}

1. Егоров, Е.А. Сортимент винограда местной селекции для производства вин высшей категории качества / Е.А. Егоров, Н.М. Агеева, Т.И. Гугучкина, М.И. Панкин // Виноделие и виноградарство. - 2016. - № 2. - С. 25-30.

2. Ильницкая, Е.Т. Новые сорта винограда для качественного красного виноделия, адаптированные к нестабильным условиям зимнего периода / Е.Т. Ильницкая, Т.А. Нудьга, О.Н. Шелудько, А.В. Прах // Научная жизнь. - 2016. - № 2. - С. 119-128. 
Плодоводство и виноградарство Юга России № 52(04), 2018 г.

3. Ильницкая, Е.Т. Новые морозостойкие формы винограда селекции СКЗНИИСиВ для качественного виноделия / Е.Т. Ильницкая, Т.А. Нудьга, А.В. Прах, Е.Н. Якименко, А.И. Талаш // Виноделие и виноградарство. - 2014. - № 4. - С. 27-29.

4. Дергунов, А.В. Влияние особенностей новых красных сортов винограда на биохимический состав и качество вин / А.В. Дергунов // Магарач. Виноградарство и виноделие. - 2015. - Т. 45. - С. 75-79.

5. Гугучкина, Т.И. Биохимический состав виноградного сусла из интродуцированных итальянских сортов и клонов / Т.И. Гугучкина, Г.Ю. Алейникова, А.В. Прах, М.А. Грюнер, Б.В. Чигрик, А.В. Кретов // Виноделие и виноградарство. - 2011. - № 1. C. $16-19$.

6. Никулушкина, Г.Е. Новые перспективные сорта винограда селекции АЗОСВиВ для производства высококачественных вин / Г.Е. Никулушкина, С.В. Щербаков, А.П. Хмыров, А.В. Дергунов, С.А. Зотин // Виноделие и виноградарство. - 2009. - № 3. - С. 34-36.

7. Ильяшенко, О.М. Совершенствование сортимента винограда Краснодарского края на основе сравнительного изучения новых интродуцированных клонов / О.М. Ильяшенко, А.В. Дергунов, Е.В. Волкова, С.А. Лопин, Ю.А. Разживина // Виноделие и виноградарство. - 2012. - № 4. - С. 41-44.

8. Авидзба, А.М. Антиоксидантная активность продуктов переработки красных сортов винограда «Каберне-Совиньон», «Мерло», «Саперави» / А.М. Авидзба, А.В. Кубышкин, Т.И. Гугучкина, В.А. Маркосов [и др.] // Вопросы питания. - 2016. T. 85. - № 1. - С. 99-109.

9. Агеева, Н.М. Антиоксидантные и антирадикальные свойства красных виноградных вин / Н.М. Агеева, В.А. Маркосов, Г.Ф. Музыченко [и др.] // Вопросы питания. - 2015. - Т. 84. - № 2. - С. 63-67.

10. Шелудько, О.Н. Технологические приемы и сортовые особенности производства столовых сухих красных вин из новых сортов винограда / О.Н. Шелудько, Т.И. Гугучкина, Н.К. Стрижов // Виноделие и виноградарство. - 2015. - № 3. - С. 25-28.

11. Гугучкина, Т.И. Создание высококачественных продуктов переработки винограда на основе использования сортов селекции СКЗНИИСиВ, интродуцированных сортов и новых приемов в виноделии / Т.И. Гугучкина // Виноделие и виноградарство. 2016. - № 4. - С. 7-12.

12. Гугучкина, Т.И. Биохимический состав виноматериалов из интродуцированных сортов винограда, выращенных в условиях Темрюкского района Краснодарского края / Т.И. Гугучкина, Е.Н. Якименко, А.В. Прах, Л.П. Трошин // Научный журнал КубГАУ. - 2014. - № 101. - С. 136-150. - URL: http://ej.kubagro.ru/2014/07/pdf/09.pdf (дата обращения: 30.05.2018).

13. Jackson, R.S. Wine Science. Principles and applications (Fourth edition) / R.S. Jackson. - Elsevier: - 2014. - 920 p.

14. Foroni, F. The smell of terroir! Olfactory discrimination between wines of different grape variety and different terroir / F. Foroni and el. // Food Quality and Preference. 2017. - V. 58. - P. 18-23.

15. Ziółkowska A. Differentiation of wines according to grape variety and geographical origin based on volatiles profiling using SPME-MS and SPME-GC/MS methods / A. Ziółkowska, E. Wąsowicz, H.H. Jeleń // Food Chemistry. - 2016. -V. 213. - P. 714-720.

\section{References}

1. Egorov, E.A. Sortiment vinograda mestnoj selekcii dlya proizvodstva vin vysshej kategorii kachestva / E.A. Egorov, N.M. Ageeva, T.I. Guguchkina, M.I. Pankin // Vinodelie i vinogradarstvo. - 2016. - № 2. - S. 25-30. 
2. Il'nickaya, E.T. Novye sorta vinograda dlya kachestvennogo krasnogo vinodeliya, adaptirovannye $\mathrm{k}$ nestabil'nym usloviyam zimnego perioda / E.T. Il'nickaya, T.A. Nud'ga, O.N. Shelud'ko, A.V. Prah // Nauchnaya zhizn'. - 2016. - №2 - - S. 119-128.

3. Il'nickaya, E.T. Novye morozostojkie formy vinograda selekcii SKZNIISiV dlya kachestvennogo vinodeliya / E.T. Il'nickaya, T.A. Nud'ga, A.V. Prah, E.N. YAkimenko, A.I. Talash // Vinodelie i vinogradarstvo. - 2014. - №4. - S. 27-29.

4. Dergunov, A.V. Vliyanie osobennostej novyh krasnyh sortov vinograda na biohimicheskij sostav i kachestvo vin / A.V. Dergunov // Magarach. Vinogradarstvo i vinodelie. - 2015. - T.45. - S. 75-79.

5. Guguchkina, T.I. Biohimicheskij sostav vinogradnogo susla iz introducirovannyh ital'yanskih sortov i klonov / T.I. Guguchkina, G.YU. Alejnikova, A.V. Prah, M.A. Gryuner, B.V. CHigrik, A.V. Kretov // Vinodelie i vinogradarstvo. - 2011. - № 1. - S. 16-19.

6. Nikulushkina, G.E. Novye perspektivnye sorta vinograda selekcii AZOSViV dlya proizvodstva vysokokachestvennyh vin / G.E. Nikulushkina, S.V. Shcherbakov, A.P. Hmyrov, A.V. Dergunov, S.A. Zotin // Vinodelie i vinogradarstvo. -2009. - №3. S. 34-36.

7. Il'yashenko, O.M. Sovershenstvovanie sortimenta vinograda Krasnodarskogo kraya na osnove sravnitel'nogo izucheniya novyh introducirovannyh klonov / O.M. Il'yashenko, A.V. Dergunov, E.V. Volkova, S.A. Lopin, YU.A. Razzhivina // Vinodelie i vinogradarstvo. - 2012. - № 4. - S. 41-44.

8. Avidzba, A.M. Antioksidantnaya aktivnost' produktov pererabotki krasnyh sortov vinograda «Kaberne-Sovin'on», «Merlo», «Saperavi»/ A.M. Avidzba, A.V. Kubyshkin, T.I. Guguchkina, V.A. Markosov [i dr.] // Voprosy pitaniya. - 2016. - T. 85. - № 1. S. 99-109.

9. Ageeva, N.M. Antioksidantnye i antiradikal'nye svojstva krasnyh vinogradnyh vin / N.M. Ageeva, V.A. Markosov, G.F. Muzychenko [i dr.] // Voprosy pita-niya. - 2015. T. 84. - № 2. - S. 63-67.

10. SHelud'ko, O.N. Tekhnologicheskie priemy i sortovye osobennosti proizvodstva stolovyh suhih krasnyh vin iz novyh sortov vinograda / O.N. Shelud'ko, T.I. Guguchkina, N.K. Strizhov // Vinodelie i vinogradarstvo. - 2015. - № 3. - S. 25-28.

11. Guguchkina, T.I. Sozdanie vysokokachestvennyh produktov pererabotki vinograda na osnove ispol'zovaniya sortov selekcii SKZNIISiV, introducirovannyh sortov i novyh priemov v vinodelii / T.I. Guguchkina // Vinodelie i vinogradarstvo. - 2016. - № 4. S. 7-12.

12. Guguchkina, T.I. Biohimicheskij sostav vinomaterialov iz introducirovannyh sortov vinograda, vyrashchennyh v usloviyah Temryukskogo rajona Krasnodarskogo kraya / T.I. Guguchkina, E.N. YAkimenko, A.V. Prah, L.P. Troshin // Nauchnyj zhurnal KubGAU. 2014. - № 101. - S. 136-150. - URL: http://ej.kubagro.ru/2014/07/pdf/09.pdf (data obrashcheniya: 30.05 .2018$)$.

13. Jackson, R.S. Wine Science. Principles and applications (Fourth edition) / R.S. Jackson. - Elsevier: - 2014. - 920 p.

14. Foroni, F. The smell of terroir! Olfactory discrimination between wines of different grape variety and different terroir / F. Foroni and el. // Food Quality and Preference. 2017. - V. 58. - P. 18-23.

15. Ziółkowska A. Differentiation of wines according to grape variety and geographical origin based on volatiles profiling using SPME-MS and SPME-GC/MS methods / A. Ziółkowska, E. Wąsowicz, H.H. Jeleń // Food Chemistry. - 2016. -V. 213. - P. 714-720. 